\title{
Potential analysis of the Templar Castle of Monzón in Huesca, Spain as a tourist attraction
}

\author{
M. Morant ${ }^{1}$, P. Alonso-Monasterio ${ }^{1}$, M. J. Viñals ${ }^{1} \&$ L. Teruel $^{2}$ \\ ${ }^{I}$ Department of Cartographic Engineering, Geodesy and \\ Photogrammetry, Universitat Politècnica de València, Spain \\ ${ }^{2}$ Department of Economics and Social Sciences, \\ Universitat Politècnica de València, Spain
}

\begin{abstract}
The Monzón castle is a historical fortress located in the Huesca province in Aragón, Spain. A tower, which was constructed by the Moors during the 10th century, was expanded into the castle by the monarchs of Aragón in 1089. After 1143, the castle was inhabited by the Knights Templar. The soldier-monks transformed the castle into a convent with military Cistercian buildings that included walls, tower, stables, etc. The future King of Aragón, James I "the Conqueror", received his primary education at the castle. It was designated as a National Monument in 1949. Recently, the castle was included in the Spanish "Domus Templi" route along the Ebro River and the Mediterranean coast, which links the five magnificent Templar castles of Monzón, Gardeny, Miravet, Tortosa and Peñíscola.

The master plan prepared to ensure the preservation of the Monzón castle includes proposals to enhance its potential for tourism. The present paper presents the key proposals for the tourism enhancement of the castle and its surroundings that were developed in the master plan. The proposals focus on the site's architectural heritage, surrounding landscape, and ethnographic elements as well as existing services, infrastructure and facilities. The results of this analysis provide information regarding the castle's potential as a tourist attraction and identify urgent issues that must be addressed if the site is to become a marketable tourism product.
\end{abstract}

Keywords: defence heritage, Templar castle, potential analysis, cultural tourism. 


\section{Introduction}

As in many other Mediterranean countries, the economies of towns in the interior of Spain typically have been based upon sectors that were not related to tourism, such as agriculture or industry. The rise of cultural tourism in recent years has provided towns and villages with an unrivalled opportunity to diversify their economies.

However, the presence of outstanding cultural heritage elements alone does not guarantee the presence of tourists. Therefore, if cultural assets are to attract tourists, planning [1] and analysis of the site's potential as a tourist attraction are necessary to establish a foundation for tourism activity. The analysis can be applied at any stage of development of the tourism activity cycle [2]. Whether the site is a nascent or mature destination, the analysis should provide the planners with a comprehensive description of the situation.

Juan [1] defined a cultural heritage product as a cultural resource that can be developed for certain activities, primarily visits open to the public. Thus, to become a marketable opportunity, a heritage element must first be transformed into a cultural heritage tourism product, which requires addressing issues such as accessibility, complementary offerings, signage and hospitality services. Robb [3] agrees with Juan [1] that it can be profitable, but adds that it requires packaging and promotion.

Furthermore, the emergence of cultural tourism has increased the need to respond to visitor demands for quality and satisfaction, to broaden the scope of the offering, and to distinguish the destination from similar sites by identifying its unique and authentic characteristics [4].

In the area of cultural tourism, castle and fortress tourism is a specific trend, in which the built heritage forms the core of the visitor's motivation. López and Gómez [5] defined this type of tourism as a tourism that embraces change and makes it possible for visitors to admire and establish contact with a complex monument of military or defence character, to engage with the past, and to experience artistic, folkloric, gastronomic and cultural demonstrations.

The primary goal of the present research was to identify and analyse the cultural tourism potential of the Monzón Templar castle and its surroundings to enhance its value and facilitate the development of attractive tourism products.

Many countries have developed cultural tourism that focuses on fortress and castle tourism. Stojsavljevic et al. [6] identify numerous examples of welldocumented medieval cultural resources throughout Europe that include castles in England (e.g., Windsor, Lincoln, and Dover), in Scotland (e.g., Bothwell, Caerlaverock, and Edinburgh), in Ireland (e.g., Blarney and Dublin), in Wales (e.g., Caerphilly and Conwy), in France (e.g., Avignon, Foix, and Mont-SaintMichel), in Italy (e.g., Bari, San Gimigniano, Fenis, and Sacra di San Michele), in Germany (e.g., Neuschwanstein) and in Eastern Europe (e.g., Ciechanow in Poland; Karlstein in the Czech Republic; Bran in Romania and Kalemegdan, Smederevo and Golubac in Serbia). Many visitors travel to these fortifications; for example, there are from 10,000 to 12,000 visits per year to Golubac and from 26,000 to 30,000 visits to Smederevo. In the case of well-documented medieval 
heritage sites visited by international travellers, Windsor castle is probably the most visited site, with 7.3 million visitors to the Royal Borough each year [7], followed by Carcassonne, with more than 4 million visitors every year [8] and Brand castle, with more than 500,000 visitors per year [9].

In response to the need to diversify tourism offerings in Spain, cultural tourism has been one of the primary tourism sectors promoted by national authorities for a number of years. Turespaña (the Spanish agency in charge of marketing international tourism) found that $61.7 \%$ of tourists engaged in cultural activities during their stay in Spain in its most recent study of the Spanish cultural tourism in 2011 [10].

Castle and fortress tourism is well represented in Spain and includes outstanding products that have been conceived as thematic routes (with 23 cultural routes). For example, the 'Cathars Spanish Route' in the Catalonian region south of France follows the migration route used by the Cathars or "good men" fleeing the persecution of the crusaders and the Inquisition during the 12th and 14th centuries [11]. The 'Route of the Vinalopó's Castles' in the Alicante region includes 11 castles along the Vinalopó river that exemplify the Arab occupation at these locations [12]. In the Aragón region, which is the location of the Monzón castle, there are many cultural tourism initiatives that focus on routes and defence heritages [13] such as 'The Mudéjar Route' that includes UNESCO World Heritage sites, the 'Saint James Ebro River Way', the 'Monasteries Route', the 'Roman Route' and 'Goya's Route'.

With respect to Templar castles and other heritage sites related to this religious order, the 'Spanish Domus Templi Route' along the Ebro river and the Mediterranean coast created in the Aragón region in 2002 includes the magnificent Templar castles of Gardeny, Miravet, Tortosa and Peñíscola in addition to the Monzón castle [14].

\section{The Monzón Templar castle}

The Monzón Templar castle is a medieval defence structure located in the province of Huesca in the Aragón region in northwest Spain. Since 1089, the year in which the Muslim village of Monzón was conquered by Christians, this castle has witnessed many outstanding events over its long and intricate history.

From an architectural perspective, the Monzón castle is a heterogeneously constructed defensive fortress. Despite various refurbishments and restoration work, the irregular polyhedral plan retains its original structure and integrity, which resulted in its designation as a National Monument in 1949 (fig. 1).

When the Monzón castle was granted to the Templars as an encomienda in 1143, it flourished as the most important Templar castle in the Aragón Kingdom. Under the management of 'The Poor Fellow-Soldiers of Christ and of the Temple of Solomon' (an order famous not only in battle but also as skilful administrators), the Monzón castle was a major administrative centre [16], and the dormitories, the chapel, the Refectory and the King James I tower were added. The King James I tower owes its name to the widespread belief that King James I 'the Conqueror' was educated at the castle. 


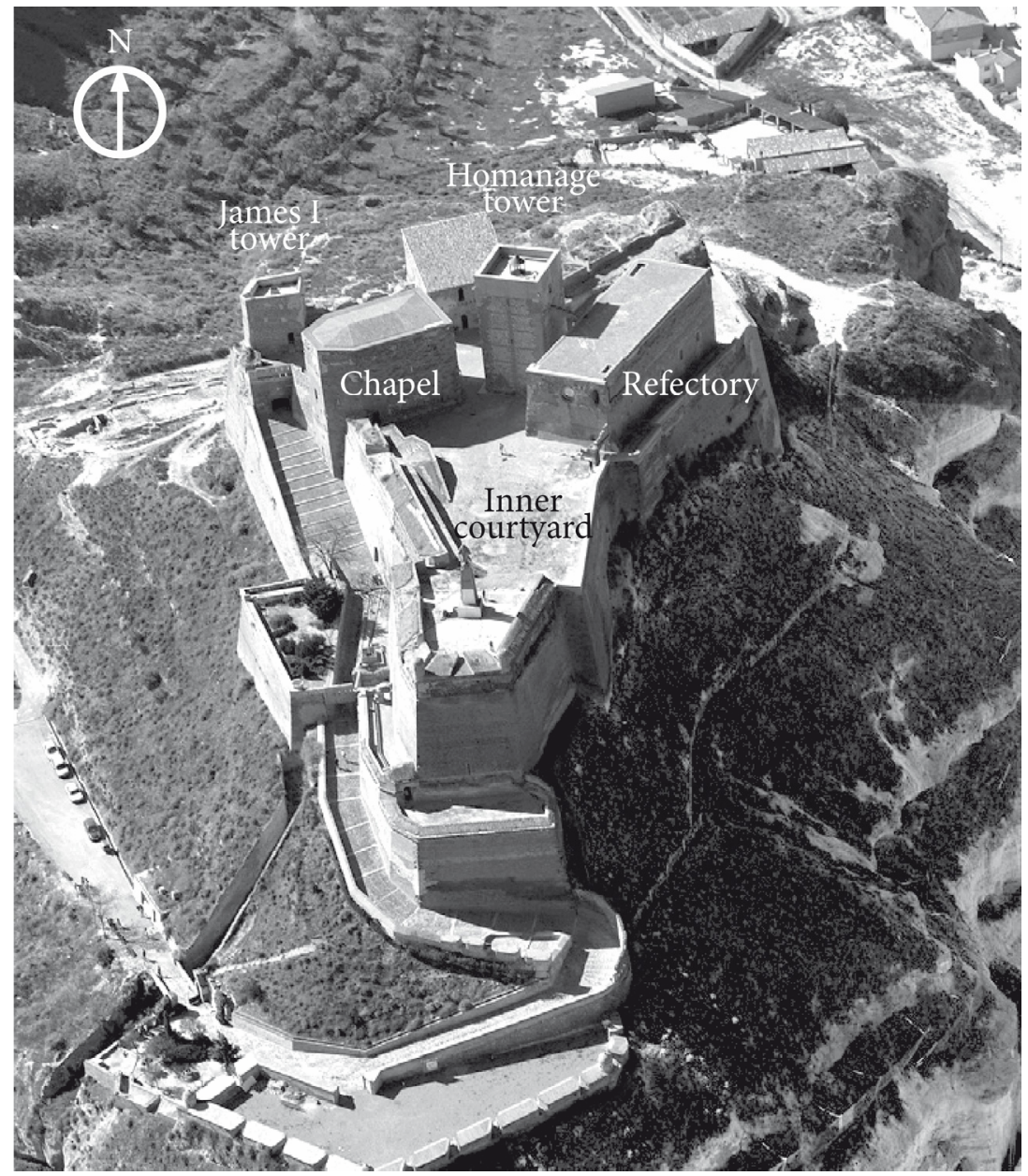

Figure 1: Aerial view of Monzón castle and its primary structures. Prepared by the authors from an image by Vegas et al. [15].

The Monzón castle is also famous as the site of the final resistance of the Templar knights in Spain before it was ultimately transferred to the Knights Hospitaller in 1312. In the 18th century, the castle was adapted to the burgeoning use of fire armaments, which transformed the medieval fortress into a modern military establishment. It was restored in the 20th century, and currently few traces of the 18th century transformations remain [15].

With respect to current visitor activities, the castle received 10,000 visitors per year on average from 2003 to 2010 [17-20]. The number of visitors has increased in recent years (see table 1). In 2013, there were more than 13,000 visitors due to the addition of dramatisations for visitors in collaboration with local hotels and 
hostels offering castle entrance to guests for the symbolic fee of $1 €$, the availability of audio guides in four languages and communication initiatives [21-23].

Table 1: Number of visitors to Monzón castle.

\begin{tabular}{|c|c|c|c|c|c|c|c|c|}
\hline Year & $\begin{array}{c}\text { Visitors } \\
\text { per year }\end{array}$ & $\begin{array}{c}\text { January- } \\
\text { March }\end{array}$ & $\begin{array}{c}\text { Easter } \\
\text { holidays }\end{array}$ & July & August & October & November & December \\
\hline $\mathbf{2 0 0 3}$ & $<10,000$ & & & & & & & \\
\hline $\mathbf{2 0 0 4}$ & 11,123 & 1,200 & 1,400 & & 1,400 & 1,100 & & 1,854 \\
\hline $\mathbf{2 0 0 8}$ & 8,800 & & & & & & & \\
\hline $\mathbf{2 0 0 9}$ & 9,500 & & & & & & & \\
\hline $\mathbf{2 0 1 0}$ & 10,050 & 1,300 & 1,470 & & & & 574 & \\
\hline $\mathbf{2 0 1 1}$ & & & & 400 & & & 1,050 & \\
\hline $\mathbf{2 0 1 2}$ & & & & 800 & & & & \\
\hline $\mathbf{2 0 1 3}$ & $>13,000$ & & & & & & & \\
\hline
\end{tabular}

In this context, the Directorate General for the Heritage of the Government of Aragón, which is responsible for managing the Monzón castle, entrusted the Universitat Politècnica de València, Spain, with the task of preparing a master plan that included the goal of enhancing tourism at the castle.

\section{Methodology}

The current study primarily used the Potential Analysis method to evaluate specific characteristics of the tourism assets and their recreational value. The analysis employed relevant criteria to assess the site's ability to attract tourists, fulfil the needs of tourism activity and simultaneously ensure both heritage preservation and visitor satisfaction.

The analysis primarily involved performing an inventory that identified the iconic resources as well as existing facilities and services and assessing the identified resources to obtain the data needed to develop tourism products.

The research also involved in-depth interviews of stakeholders and service providers because the participation of both groups is critical for establishing marketable tourism products.

\section{Results of the potential analysis}

This section describes the evaluation of the recreational potential of the Monzón castle and its surroundings in Cinca Medio County to facilitate decisions regarding recreational activities based on their current attractiveness.

After the resource inventory was completed, the intrinsic value of the resources was assessed. The assessment of the intrinsic value of the resources was based on the criteria of significance, representativeness and uniqueness. A subsequent recreational assessment identified the tourism value of the resources based on criteria such as fragility, availability in terms of time and space, feasibility, accessibility and suitability for educational and cultural purposes [24, 25]. 
The main tourist resource identified by the intrinsic assessment was the historical structure of Monzón castle due to its important archaeological, architectural and historic value and because it presents the best preserved structure on the 'Domus Templi Route'. The natural and cultural assets in the castle surroundings (e.g., the fauna and flora, landscapes, ethnographic elements, etc.) serve as complementary resources.

Applying the recreational criteria identified the following concerns:

Fragility is defined as vulnerability to disturbance, typically disturbance due to human activity, and the concomitant probability of destruction or alteration. Because all the analysed resources exhibited a moderate degree of fragility, appropriate measures to prevent their degradation must be implemented.

The landscape exhibits moderate to high visual fragility because the castle is located on top of a hill with many observation points and panoramic views. Currently, the landscape quality is acceptable, but elements with a disruptive impact on the landscape are visible due to the lack of vegetation.

With respect to the remaining built environment surrounding Monzón, there is a risk of loss of monument authenticity.

Local crafts are one of the most important cultural elements of the area. However, because there are few workshops for artists and artisans wishing to maintain local traditions, this resource is vulnerable. There are no local artisan networks or mechanisms for craft distribution and sale. The current number of art celebrations and product fairs is insufficient; on-going activities throughout the year are needed.

Gastronomic resources exhibit a moderate degree of fragility because there is no guide to area restaurants and establishments that informs visitors where they might taste and buy local agri-products.

With respect to natural resources, Cinca Medio County is traversed by the Cinca River, which provides space for the transit of the migratory birds. The valley is protected by international agencies as a Special Protection Area for Birds (IBA), and the Gesa of La Almunia is a Site of Community Interest (SCI). Thus these natural sites exhibit a moderate to high degree of vulnerability, depending on the particular species and activities performed.

Attractiveness is based on aesthetic, emotional [26] and perceptual characteristics such as beauty, originality, and symbolism; this primarily subjective component is associated with visitor preferences that are related to factors such as age, genre, culture, education, and nationality.

The aesthetic, emotive and experiential value of the Monzón castle, which is due to the castle's magnificence, beauty, cultural meaning, social importance, and the high quality of the restoration efforts, contributes greatly to its attractiveness. In addition, the panoramic views of the landscape from the castle present an interesting, well-preserved cultural landscape based on traditional agroecosystems that evoke, symbolic and emotional meaning.

With respect to the other existing historic and artistic heritage in the town, the raval of the medieval city and certain buildings (e.g., the Luzan Palace and the Renaissance Main Square) serve as complementary tourist attractions. The 
stately family homes throughout the countryside are another element that tour itineraries should consider.

Local handicrafts represent a major tourist attraction. In the case of Monzón, craft production and purchases might become important if associated with other tourist activities and resources. Moreover, Monzón and the surrounding area have a rich gastronomy that might contribute to a satisfying emotional experience if high product quality can be combined with high quality service.

Despite its fragility, the avifauna might contribute to tourism enhancement in the Cinca Medio region if well-managed to guarantee conservation. Moreover, there are many short walking trails (PR), long-distance trails (GR) and local paths (SL) in the region that could contribute to interpretative activities that take advantage of the Centre of Interpretation of the Cinca Pinzana.

Availability of time and space resources is related to opportunities for visiting, admissions and seasonality. For Monzón castle, availability is closely linked to the weather because it is an open air structure. Availability is high because the area enjoys a Mediterranean climate.

With respect to fauna, seasonality also influences resource value because most of the species in the Cinca Medio region are migratory birds.

Feasibility refers to the internal and external impact of tourism activity with respect to economic viability, which requires the assessment of cost and benefits, acquisition costs, restoration costs, management and maintenance costs, as well as social benefits and stakeholder attitudes. It is also related to the management expertise of the institution that is responsible for preservation.

With respect to the castle, social benefits have provided the key motivation driving the master plan for restoration that includes the present study of the castle's tourism potential. The plan constitutes the starting point for action by responsible authorities such as the General Directorate for Cultural Heritage of Aragón and the municipality of Monzón to preserve and maintain the monument, as well as a guide for future investment to increase the number of visitors and achieve economic benefits. Although public institutions have provided recreational activities and tourism development, the plan reveals that current efforts are insufficient. The lack of a strategic vision that integrates the Monzón castle with the complementary offerings of other tourist attractions in the surrounding area has resulted in the failure to invest in projects.

Accessibility refers to visitors' ability to physically access the attraction. There are natural obstacles such as high inclines that make the site difficult to access. Accessibility also involves the availability of facilities such as highways, roads, recreational facilities and services, signage, and transports [27]. First, it is important to note that a recent road created to by-pass the town diverts tourists away from the town. With respect to castle facilities, the monument currently possesses effective directional signage and interpretative information, tours of different parts of the castle, permanent exhibitions, a visitor centre equipped with audio-visual and interpretative panels and a conference room. However, although the Monzón castle is accessible to the general public, handicapped individuals are hampered by high inclines and pavement that does not facilitate access to all parts of the castle. Thus, it would be appropriate to move the visitor centre to the outset 
of the tour to improve access for groups that might have experience difficulties with access.

The content and facilities provided on the routes through the Castle are appropriate and the current state of preservation allows regular visitor use.

Tourism activities based on the historic, ethnographic and urban heritage of the town of Monzón and its surroundings (e.g., the Cathedral of Santa Maria of Romeral, the old Jewish Quarter, the Palace of Luzan, the Main Place and certain museums) could be expanded by including other monuments in the neighbouring municipalities in the Cinca Medio region. Although these resources are highly accessible, currently spontaneous visits are hindered by the lack of interpretative and informative signage.

Accessibility to natural resources is high and there is also a wide array of pedestrian, cycling and equestrian activities associated with an extensive network of footpaths. For better accessibility to these resources, existing signage, rest areas and recreation facilities should be improved, and printed or digital materials with information about the recreational activities in the region should be produced.

Suitability for educational and interpretive purposes is excellent due to the resource's educational value. A program that combines excellent thematic interpretation with appropriate information highly enhances the attractiveness of the resource due to the added emotional and intellectual value it provides.

The Monzón castle provides unparalleled opportunities for heritage interpretation and education. Compared to learning from secondary sources, the first-hand knowledge provided by the castle's authentic historical structures and the cultural regional traditions provide a direct link to the past.

\section{Conclusions}

In summary, the Monzón castle's magnificent architecture and historical relationship to the Knights Templar make it a valuable cultural resource for the development of tourism for castle and fortress visitors.

In the past, tourism activity development in Monzón and its surroundings was spontaneous and did not follow methodological guidelines or require coordination among the various institutions involved, which resulted in a fragile tourism model that developed without consensus or coordination. The present research reveals that a major weakness of current tourism in Monzón and its environment is the absence of a strategic vision and the lack of a product concept that markets and positions Monzón as a travel destination. The present analysis documents that current tourism has poorly utilised the natural and cultural resources of the area, despite the presence of a significant number of resources that could serve as attractive tourism offerings.

To improve this situation, the tourism development plan for the Monzón castle and its environment in the near future should improve the available cultural and natural resources by increasing their attractiveness, promoting local gastronomy, creating complementary offerings linked to agri-food products and crafts, improving and increasing accommodation offerings, improving the quality of 
service provided by the human resources, and engaging in communication and marketing efforts.

To take advantage of the opportunities that tourism development provides, the administration must coordinate the above initiatives to both guarantee heritage conservation and ensure that the process is participative, with local community involvement and public-private partnerships.

\section{References}

[1] Juan, J., El patrimonio como generador de desarrollo a partir del turismo. $V$ Jornada sobre Gestión del Patrimonio Sostenible: El patrimonio como elemento dinamizador del territorio. Fundación Abertis: Madrid, Spain, pp. 15, 2005. http://www.fundacioabertis.org/rcs_jor/2005_patrimonio_ tresserras.pdf

[2] Butler, R.W., The concept of a tourist area cycle of evolution: implications for management of resources. Canadian Geographer, 24, pp. 5-12, 1980.

[3] Robb, J.G., Tourism and Legends. Archaeology of Heritage. Annals of Tourism Research, Vol. 25, No. 3, pp. 579-596, 1998.

[4] Moscardo, G.M. \& Pearce, P.L., Historic Theme Parks: An Australian Experience in Authenticity. Annals of Tourism Research, 13, pp. 467-479, 1986.

[5] López, F. \& Gómez, B., Nuevos Productos de Turismo Cultural: Castillos y Fortalezas en Cataluña, Proc. of the IV Coloquio de Geografia Urbana; $y$ VI Coloquio de Geografia del Turismo, Ocio y Recreación, ed. Morales, G, Biblioteca Virtual Miguel de Cervantes: Alicante, pp. 155-162, 2000.

[6] Stojsavljevic, R.; Vujicic, M., Djercan, B. \& Djurdjev, B., Serbian Medieval Towns and their Tourist Potentials. Geographica Timisiensis, vol. 19, nr. 1, pp. 189-196, 2010.

[7] Visitor Management \& Marketing; Royal Borough of Windsor \& Maidenhead. http://www.windsor.gov.uk/statistics-and-data/visitormanagement-and-marketing

[8] Introducing Carcassonne; Lonely Planet. http://www.lonelyplanet.com /france/languedoc-roussillon/carcassonne

[9] The most visited place in Romania: Bran Castle - "Dracula" Castle; Romanian Journalist. http://romanianjournalist.wordpress.com /2013/05/09 /the-most-visited-place-in-romania-bran-castle-or-dracula-castle/

[10] Instituto de Estudios Turísticos, Estudios de productos turísticos: Turismo Cultural de turistas extranjeros año 2011, Instituto de Turismo de España (Turespaña): Madrid, pp. 50, 2012.

[11] Consell Regulador del Camí dels Bons Homes, Camí dels Bons Homes $i$ Camí de l'Últim Càtar, http://www.camidelsbonshomes.com/travessa.htm

[12] Club de producto de Turismo Cultural de la Costa Blanca, Instituto Universitario de Investigaciones Turísticas (IUIT), Ruta de los Castillos del Vinalopó, http://www.rutacastillosvinalopo.net/espa\% $\% 3 \% \mathrm{~B} 1 \mathrm{ol} /$ folletocolor/ 
[13] Presidencia de la Diputación General de Aragón, Ley 12/1997, de 3 de diciembre, reguladora de los Parques Culturales de Aragón, 1997.

[14] Consorci de la Ruta el Temple, Domus Templi, Dominios del Temple, Corona de Aragón, http://www.domustempli.com/

[15] Vegas, F; Mileto, C. \& Cristini, V., "Planning a plan" Steps and development of Monzón's Castle's Masterplan (Huesca). Arché. Publicación del Institutto Universitario de Restauración del Patrimonio de la UPV, Num. 4 y 5, pp. 365-372, 2010.

[16] Ortiz, J., Domus Templi: Castillos templarios en el Reino de Aragón. Escritura pública, (45), 82-86, 2007.

[17] Aragón Digital, El castillo de Monzón recibió durante 2004 más de once mil visitants, 10/1/2005.

[18] Radio Huesca, El Castillo de Monzón atraviesa un buen momento, $11 / 06 / 2010$.

[19] Radio Huesca, Romper la barrera de los 10.000 visitantes año para el castillo de Monzón, reto del área de Turismo, 26/01/2011.

[20] AACA Asociación Amigos de los Castillos de Aragón, Exito de visitantes en el castillo de Monzón, 2011.

[21] Hoy en Aragón, El castillo de Monzón suma siete meses de incremento de visitantes, 2012

[22] El Periódico de Aragón, El castillo ofrecerá visitas teatralizadas a los visitante, 25/03/2013.

[23] Radio Huesca, Nuevo récord de visitantes en el Castillo de Monzón durante 2013, 02/02/2014.

[24] Viñals, M.J., Filiberto, I. \& Morant, M., Manual para o inventário dos valores culturais das Zonas Húmidas / Manual para el inventario de los valores culturales de los humedales. Ed. Instituto da Conservaçao da Natureza, Ministério do Ambiente (Portugal), 179 pp, 2005.

[25] Viñals, M.J., Morant, M. \& Quintana, R., Análisis de los criterios para la valoración turística del patrimonio natural. Revista de Investigaciones turísticas $N^{o} 1$, Instituto Universitario de Investigaciones Turísticas de la Universidad de Alicante, pp. 37-50, 2011.

[26] Ham, S.H. Environmental Interpretation. A practical guide for people with big ideas and small budgets. Ed. Fulcrum Publishing, 456 pp, 1992.

[27] Gudinwki, H., Furniss, M.J., Ziemer, R.R. \& Brookes, M.H., Forest Roads: A Synthesis of Scientific Information. Portald (OR): USDA Forest Service, Pacific Northwest Research Station, General Technical Report PNW-GTR$509,2001$. 